\title{
The Relationships Between Mindfulness and Valued Living in University Students: The Mediating Role of Authenticity
}

\author{
Ferah Çekici ${ }^{1}$ \\ ${ }^{1}$ School of Psychological Counseling and Guidance, İstanbul Medipol University, İstanbul, Turkey \\ Correspondence: Ferah Çekici, School of Psychological Counseling and Guidance, İstanbul Medipol University, \\ Göztepe Mah. Atatürk Cad. No: 40, İstanbul, Turkey.
}

Received: June 20, 2019

doi:10.5539/ies.v12n11p148
Accepted: July 30, 2019 Online Published: October 28, 2019

URL: https://doi.org/10.5539/ies.v12n11p148

\begin{abstract}
It was aimed to examine the mediating role of authentic behavior on mindfulness and valued-living in this study. The study group involved the participation of a total of 270 undergraduate students and the students' age was between 18-28 years old. The group's mean age was $20.4(\mathrm{Sd}=1.44)$. The data were collected through The Mindful Attention and Awareness Scale, Valued Living Questionnaire and Authenticity Scale.The hierarchical regression analysis was used to analyze the mediating role of authenticity. The results of this study showed that authenticity has a mediating role on the relationship between mindfulness and valued-living.
\end{abstract}

Keywords: valued living, mindfulness, authenticity, mediation, university students

\section{Introduction}

In the psychology discipline, values have been studied variously. According to the related literature, Rokeach (1973) and Schwartz's (1992) studies had a lot of contributions and their studies are pioneer in this field through working on listing the value tendencies (Wilson, Sandoz, Kitchens, \& Roberts, 2010). But in recent years, Acceptance and Commitment Therapy (ACT) presented a new paradigm about values. This concept was called "valued living". According to many researches, it was concluded that there was significant relations between valued living and many variables like mindfulness, psychological adversities, psychological adaptation and life satisfaction, (Hayes et al., 2006; Strosahl et al., 2004; Wilson \& Murrell, 2004). From this point, the present study, tested the mediator role of authentic behavior on the relationship between mindfulness and valued-living.

\subsection{Valued Living and Mindfulness}

The concept of the valued-living which was firstly described by the ACT is a manner that the extent to which an individual contacts his or her chosen values in everyday life. In the ACT, valued living is also measured by two dimensions; the importance of values and the consistency in living their life with the values. The importance of the values generally describes the level of the importance that the individuals attach to the variety of values such as family, intimate relationships, work, education etc. The consistency in living their life with values means that how consistently individuals live their lives according to their values (Hayes et al., 1999; Wilson, Sandoz, Kitchens, \& Roberts, 2010). In another words, consistency in living their lives with values is evaluating whether individuals live "value-oriented lives" or not (Hayes et al., 1999). On the contrary to the previous studies on values (Rokeach, 1973; Schwartz, 1992), the concept of valued-living in ACT has revealed a new perspective in values of researches (Hayes et al., 1999). In the ACT, values have some qualifications that distinguish them from the prior value definitions. According to ACT, values are composed of five features that values are "freely chosen", "structured", "dynamic and ongoing" "evolving patterns of activity" and lastly "emerged as the internal rewards". All of these features indicate that valued living establishes intrinsic behavior patterns that have motives or tendency to live a meaningful life (Wilson, Sandoz, Kitchens, \& Roberts, 2010). Besides, values in ACT are not out in the world; on the contrary they are defined, elaborated, and constructed in an ongoing way by the clients (Wilson \& Du Frene, 2009). Traditional cognitive-behavioral therapy (CBT) has been more focused on reducing the clients' problematic thinking and maladaptive emotional process. On the contrary, in the third-wave of the behavior therapies which contain mindfulness-based therapy and ACT, emphasize acceptance, mindfulness, open to experiences and valued living instead of reducing the clients' maladaptive symptoms (Wilson, Sandoz, Flynn, \& Slater 2010). Hayes et al. (1996) indicated that there is a growing interest about using valued living in the therapy process because valued living is acclaimed to be a central concept of the treatment. For this purpose, the aim of the ACT is to accept 
suffering so that in the therapy process individuals' capacity of commitment in valued living increase (Strosahl, Hayes, Wilson, \& Gifford, 2004). When valued living literature is examined, the concept was found to have a strong association with decreased psychological distress, increased psychological adjustment, improvements in quality of life and mindful acceptance (Wilson \& Murrell, 2004). In the ACT, when individuals' attempt to decrease their difficult experiences, this results in avoidance that increases psychological distress and has a negative impact on valued living (Wilson, Sandoz, Flynn, \& Slater, 2010).

Thus, when the literature was examined, the strong relation between valued living and mindfulness was explored. Mindfulness is generally described as a form of nonjudgmental, nonreactive attention to experiences occurring in the present moment, including cognitions, emotions and bodily sensations, as well as sight, sounds, smells and other environmental stimuli (Kabat-Zinn, 2005). In fact, the most common definition of conscious awareness is the state of mindfulness and awareness of what is happening in the present (Brown \& Ryan, 2003). But recently, definition of mindfulness is getting wider and according to the new definitions, it consists of not only being at present but also acceptance, diffusion and transcendent of self-dimensions. Especially acceptance and diffusion are related to value living. Acceptance is an intentional attempt in which individuals get open to experience new things without attempting to decrease the suffering intensity or frequency in these experiences. To behave an accepting manner, one should be willing to experience pain or discomfort that can be made through valued living. Also, diffusion is a manner taking perspectives about the event and not to use any judgments. If a person ignores or refuses the reality or their problems he/she behave in a "fusion" manner and fusion interferes with a valued living (Wilson \& Sandoz, 2010).

As a consequence, investigating the relationship between valued-living and mindfulness yielded a strong relation. Especially when somebody wants to behave in a mindful manner, they probably promote to take steps in a valued direction (Hayes, 2013). In ACT whose central aim is to increase valued-living, mindfulness processes are immensely important in clarifying values and increasing committed action (Hayes et al., 1999; Plumb et al., 2009). In other words, in the mindfulness training process, valued living is a widely used method of classifying values as well as constructing the behavior of individuals based on values.

\subsection{The Mediating Role of Authenticity}

Authenticity is defined as "the unobstructed operation of one's true, or core, self in one's daily enterprise" (Kernis, 2003). According to this definition, it is primarily required that people realize their own feelings, opinions and motives. Sheldon (2013) suggested that authenticity consists of four dimensions. The first one is "awareness" that it is a kind of motive that ones' acting towards self-actualization. The second one is "unbiased and processing" that means the person doesn't behave in a defensive manner towards to him/herself. "Behavior dimension" is the third dimension that the consistency and accordance between one's behaviors and values, preferences and needs. The last one is "relational orientation" that individuals are to behave honestly and in trueness in interpersonal relationships. Another classification about the authenticity is created by Wood et al. (2008). They suggested that authenticity involves three components. These are self-alienation, authentic living and accepting external influence. If the person is affected by the external influences, the "self-alienation" comes out. On the contrary, lower external influences cause more authentic live. Moreover, unless the individuals' awareness does not catch the reality, psychopathology will probably occur. The second component is "authentic living" means that individuals live their life in accordance with their values and beliefs and are in true self when faced with many different situations in the life. The final component "accepting external influence" is a manner that individuals are accepting other peoples' influences on themselves and also beliefs about their expectations. In this sense, when the self-alienation and external influence levels are extremely high, the inauthenticity occurs. On the contrary, if people live their life in accordance with the values, the authenticity will happen. In this sense, people who live their life based on the values are tended to be in an authentic existence. Besides, Heppner and Kernis (2007) claimed that mindfulness and authenticity are interrelated. Higher levels of mindfulness are related to more self-congruence (Brown and Ryan, 2003). After all, the present research is aimed to examine the mediating role of the authentic behavior between mindfulness and valued living.

\section{Method}

\subsection{Research Method}

This research is an example of descriptive-correlational study which is a type of quantitative research.

\subsection{Participant (Subject) Characteristics and Sampling Procedures}

270 undergraduate students (206 female, 64 male) from different programs at a private university was involved. The students' ages were ranged between 18 and 28 years old. The arithmetic mean of age was 20.4 and standard 
deviation was 1.44. Also, the convenient sampling methods were used in this study.

\subsection{Measurements}

In the present study, the data were collected using Mindful Attention and Awareness Scale, Valued Living Questionnaire and Authenticity Scale.

Mindful Attention and Awareness Scale (MAAS): This scale was developed by Brown and Ryan (2003) as a self-report measurement. The aim of the scale was to measure awareness and attention to the here and now experiences in daily life. MAAS has a single factor structure and totally 15 items. The items were rated on a six-point Likert type scale from 1 (almost always) to 6 (always never). In the original form of the scale internal consistency coefficient was found $(\alpha=0.82, n=327)$ in a student sample and $(\alpha=0.87, n=239)$ in a general adult sample. Also, test-retest reliability of the MAAS was good $(\mathrm{r}=0.81)$. In this study, Turkish form of the MAAS which adapted into Turkish by Çatak (2012) was used.

Valued Living Questionnaire (VLQ): Wilson and Groom (2002) developed VLQ as a self-statement scale that measures valued life. This scale consists of 10 life areas to measure whether the individuals live their life throughout the values or not. Also, the scale has two subscales which called "Importance" and "Coherence". Each subscale consisted of 10 items and the items were rated on a 10-point Likert type scale (1-not important-10-extremely important). In the scoring, high scores from the scale indicate that there is a value-oriented life. In this present study, the Turkish form of the VLQ which adapted into Turkish language by Çekici and colleagues (2018) was used. According to results of the Turkish form of the VLQ, internal consistency coefficient was found .90 for the whole scale.

The Authenticity Scale (AS): This scale was developed by Wood et al. (2008) as a self-report scale. The purpose of the scale was to examine the authentic behavior. The scale consisted of three-component structure such as Self-Alienation, Accepting External Influence and Authentic Life. AS has 12 items and the items were rated on a 7-point Likert type. The Turkish form of the scale was adapted by İlhan and Özdemir (2013). According to the results of the Turkish form of the AS' subscales, the Cronbach Alpha internal consistency coefficients was found, $.79, .67, .62$ respectively.

\subsection{Data Analysis Process}

After taking the ethical permission from the ethical committee, the data were collected from the undergraduate students. The participation to the study was voluntary. First of all, the purpose of the study was explained to participants and the informed consent form was filled out by them. The scales took almost 15 minutes and students filled out all the scales in the classroom. During the analyzing process, firstly the data entry was checked and missing data and outliers were removed from the data set. The assumption of the normality was tested to applying the Shapiro-Wilk Test and it was revealed that all the variables were distributed normally. Then the correlation analysis was conducted to detect the relationships between variables by using SPSS 20 (IBM, 2011). Finally, hierarchical regression analysis was used for examining the mediating role of authenticity on the relationship between mindfulness and valued-living.

\section{Results}

\subsection{Findings of Correlation Analysis}

The variables included in the study were significantly associated with each other and the scores of the Pearson Correlation Coefficients between the variables were presented in the Table 1.

Table 1. The correlation coefficients between the study variables

\begin{tabular}{lllll}
\cline { 2 - 4 } Variables & 1 & 2 & 3 \\
\hline 1. Mindfulness & - & & \\
2. Valued-living & $.12^{*}$ & - & \\
3. Authenticity & $.41^{* *}$ & $.22^{* *}$ & - \\
\hline
\end{tabular}

$\mathrm{N}=270 ; * * \mathrm{p}<.01 ; * \mathrm{p}<.05$

According to the Table 1, the variables are significantly associated with each other. It was seen that there are positive and statistically significant relationships between mindfulness - as an independent variable- and valued living $(\mathrm{r}=.12, \mathrm{p}<.05)$ and authenticity $(\mathrm{r}=.41, \mathrm{p}<.001)$. Also, there is a statistically significant and positive relationship between authenticity and valued-living $(\mathrm{r}=.22, \mathrm{p}<.001)$. 


\subsection{The Results of Hierarchical Regression Analysis}

The regression coefficient scores (both standardized and non-standardized), $t$ scores and $\mathrm{R}^{2}$ change scores of the proposed model was shown in Table 2.

Table 2. Results of hierarchical regression analysis

\begin{tabular}{lllllllll}
\hline Variables & $\mathrm{B}$ & $\mathrm{SE} B$ & $\beta$ & $\mathrm{t}$ & $\Delta \mathrm{R}^{2}$ & $\mathrm{R}^{2}$ & $\Delta \mathrm{F}$ \\
\hline Model 1 & & & & & & & \\
\hline 1. Mindfulness & .22 & .11 & .12 & $1.96^{*}$ & .014 & .014 & $3.831^{*}$ \\
\hline Model 2 & & & & & & & \\
\hline 1. Mindfulness & .07 & .12 & .04 & .56 & .034 & .048 & $9.465^{* *}$ \\
\hline 2. Authenticity & .41 & .14 & .20 & $3.07^{* *}$ & & & \\
\hline .05. & & & & & & &
\end{tabular}

According to the Table 2, the predictive role of mindfulness on valued living was tested in the first model. The first model showed that mindfulness significantly explains the variance in the valued-living $\left(R^{2}=.14, F(1,268)=3.83\right.$, $p=.051)$. Moreover, mindfulness has significant relationship with valued living $(b=.22, t(270)=1.96, p=.051$. In the second model, mindfulness and authenticity were added to the model. It was seen that the second model explains valued living at a significant level $\left(\Delta R^{2}=.34, F(2,267)=6.71, p=.001\right)$. When the predictive roles of mindfulness and authenticity were analyzed in the second model, the authentic behavior $(b=.41, t(270)=3.07, p$ $=.002)$ had a higher predictive power but mindfulness $(b=.07, t(270)=.56, p=.574)$ didn't have any significant relationship to the valued-living.

\section{Discussion}

In this research, the mediating role of the authentic behavior in the relationship is between mindfulness and valued living. According to the findings of this study, it was determined that authentic behaviors significantly predict the relationship between mindfulness and valued-living.

When related literature was examined, some studies were found out supporting this finding. Heppner and Kernis (2007) indicated that mindfulness and authenticity are interrelated. Also, the researches announced that mindfulness is positively correlated with positive psychology concepts like self-strength, coping, low level of stress and self-respect, life satisfaction, subjective well-being and positive emotions or in other words all the positive relational processes and outcomes. In this sense, when the authenticity levels increase, the positive relational processes also rise up (McKee-Ryan et al., 2005; Goldman \& Kernis, 2002). On the contrary, it was concluded that if people live their life non-authentically, there will probably be more anxiety, stress, somatic complaints, depression and less satisfaction about their life and self-respect towards their true self (Wood et al., 2008; Lopez \& Rice, 2006). According to these studies, it is probable that authentic behavior predicts or affects more positive variables rather than negative. Thus, mindfulness and valued-living processes can also be affected from authenticity.

When the literature was examined, the definition about authenticity defines variously. Kernis and Goldman (2006) focused on the "behavioral dimension" of the authenticity and they define authenticity is a manner of having a consistency between behaviors and values, needs or choices. Besides, Wood et al. (2008) emphasized "authenticity life dimension" term in which individuals live their true self throughout their values and beliefs. These definitions indicate that authentic behavior has a strong relationship to a value-oriented life. Finally, these studies support the findings of the present study that authenticity has a significant relationship to the valued-living. As a consequence, the research results indicated that authentic behavior has a significant mediating role on the relationship between mindfulness and valued life. The present study has some limitations. First of all, the study group consists of undergraduate students. Secondly, the convenient sampling method was used. In the future studies, the data could be collected from the diverse groups and random sampling methods could be used. Thirdly, in this study it was estimated that authenticity accepted as a mediator variable for the relationship between mindfulness and valued living. In the related literature it is asserted that many different variables would probably function on this relationship except to the authenticity. Lastly, self-report measurements were used to collect the data from the participants. So, it was only an assumption that participants were the volunteer in the study and filled out the scales honestly. 


\section{References}

Brown, K. W., \& Ryan, R. M. (2003). The benefits of being present: Mindfulness and its role in psychological well-being. Journal of Personality and Social Psychology, 84(4), 822-848. https://doi.org/10.1037/0022-3514.84.4.822

Çatak, D. P. (2012). The Turkish version of mindful attention awareness scale: Preliminary findings. Mindfulness, 3(1), 1-9. https://doi.org/10.1007/s12671-011-0072-3

Çekici, F., Aydın, S. Z., Malkoç, A., Aslan, G. M., \& Arslan, R. (2018). Değer odaklı yaşam ölçeği: Türk kültürüne uyarlama, geçerlik ve güvenirlik çalışması. [The valued -living questionnaire: adaptation into Turkish Culture, validity and reliability study]. Journal of Turkish Studies; Educational Sciences, 13(19), 459-471. https://doi.org/10.7827/TurkishStudies.14094

Goldman, B. M., \& Kernis, M. H. (2002). The role of authenticity in healthy psychological functioning and subjective well-being. Annals of the American Psychotherapy Association, 5(6), 18-20.

Hayes, S. C. (2013). What we are trying to do in the ACT tradition: The nature of contextual behavioral science. Colloquium presented to the University of Montreal, Canada.

Hayes, S. C., Luoma, J., Bond, F., Masuda, A., \& Lillis, J. (2006). Acceptance and commitment therapy: Model, processes, and outcomes. Behaviour Research and Therapy, 44, 1-25. https://doi.org/10.1016/j.brat.2005.06.006

Hayes, S. C., Strosahl, K. D., \& Wilson, K. G. (1999). Acceptance and commitment therapy: An experiential approach to behavior change. New York, NY, US: Guilford Press.

Hayes, S. C., Wilson, K. W., Gifford, E. V., Follette, V. M., \& Strosahl, K. (1996). Experiential avoidance and behavioral disorders: A functional dimensional approach to diagnosis and treatment. Journal of Consulting and Clinical Psychology, 64(6), 1152-1168. https://doi.org/10.1037/0022-006X.64.6.1152

Heppner, W. L., \& Kernis, M. H. (2007). "Quiet Ego" functioning: the Complementary roles of mindfulness, authenticity, and secure high self-esteem. Psychological Inquiry, 18(4), 248-251. https://doi.org/10.1080/10478400701598330

IBM Corp. (2011). IBM SPSS Statistics for Windows. Version 20.0. Armonk. NY: IBM Corp.

İlhan, T., \& Özdemir, Y. (2013). Otantiklik ölçeğinin Türkçe' ye uyarlanması: geçerlik ve güvenilirlik çalışması [Adaptation of authenticity scale to Turkish: a validity and reliability study]. Türk Psikolojik Danışma ve Rehberlik Dergisi [Turkish Psychological Counseling and Guidance Journal], 5(40), 142-153.

Kabat-Zinn, J. (2005). Coming to our senses: Healing ourselves and the world through mindfulness (1st ed.). Hachette Books. https://doi.org/10.1016/j.explore.2005.04.001

Kernis, M. H. (2003). Toward a conceptualization of optimal self-esteem. Psychological Inquiry, 14(1), 1-26. https://doi.org/10.1207/S15327965PLI1401_01

Kernis, M. H., \& Goldman, B. M. (2006). A multicomponent conceptualization of authenticity: Theory and research. In M. P. Zanna (Ed.), Advances in experimental social psychology (Vol. 38, pp. 283-357). San Diego, CA, US: Elsevier Academic Press. https://doi.org/10.1016/S0065-2601(06)38006-9

Lopez, F. G., \& Rice, K. G. (2006). Preliminary development and validation of a measure of relationship $\begin{array}{lllll}\text { authenticity. Journal of } & \text { Counseling }\end{array}$ https://doi.org/10.1037/0022-0167.53.3.362

McKee-Ryan, F. M., Song, Z., Wanberg, C. R., \& Kinicki, A. J. (2005). Psychological and physical well-being during unemployment: A meta-analytic study. Journal of Applied Psychology, 90(1), 53-76. https://doi.org/10.1037/0021-9010.90.1.53

Plumb, J. C., Stewart, I., Dahl, J., \& Lundgren, T. (2009). In search of meaning: Values in modern clinical behavior analysis. Behavior Analysis, 32(1), 85-103. https://doi.org/10.1007/BF03392177

Rokeach, M. (1973). The nature of human values. New York, NY, US: Free Press.

Schwartz, S. H. (1992). Universals in the content and structure of values: Theoretical advances and empirical tests in 20 countries. In M. P. Zanna (Ed.), Advances in experimental social psychology (Vol. 25, pp. 1-65). San Diego, CA, US: Academic Press. https://doi.org/10.1016/S0065-2601(08)60281-6

Sheldon, K. M. (2013). Authenticity (Ed. S. J. Lopez). The encyclopedia of positive psychology. Wiley-Blackwell, A John Wiley \& Sons Ltd Publication. 
Strosahl, K. D., Hayes, S. C., Wilson, K. G., \& Gifford, E. V. (2004). An ACT primer: Core therapy processes, intervention strategies, and therapist competencies. In S. C. Hayes, \& K. D. Strosahl (Eds.), A practical guide to Acceptance and Commitment Therapy (pp. 31-58). New York: Springer. https://doi.org/10.1007/978-0-387-23369-7_2

Wilson, K. G., \& Du Frene, T. (2009). Mindfulness for two: An acceptance and commitment therapy approach to mindfulness in psychotherapy. Oakland, CA: New Harbinger.

Wilson, K. G., \& Groom, J. (2002). The Valued Living Questionnaire.

Wilson, K. G., \& Murrell, A. R. (2004). Values work in Acceptance and Commitment Therapy: Setting a course for behavioral treatment. In S. C. Hayes, V. M. Follette, \& M. Linehan (Eds.), Mindfulness \& Acceptance: Expanding the cognitive-behavioral tradition (pp. 120-151). New York: Guilford Press.

Wilson, K. G., \& Sandoz, E. K. (2010). Mindfulness, values and therapeutic relationship in acceptance and commitment therapy (Chapter 6, Mindfulness and Therapeutic Relationships, Eds. S. F. Hick, \& T. Bien). New York: The Guilford.

Wilson, K. G., Sandoz, E., Kitchens, J., \& Roberts, M. (2010). The valued living questionnaire: Defining and measuring valued action within a behavioral framework. The Psychological Record, 60(2), 249-272. https://doi.org/10.1007/BF03395706

Wilson, K., Sandoz, E. K., Flynn, M. K., \& Slater, R. M. (2010). Understanding, assessing and treating values process in mindfulness and acceptance-based therapies (Chapter 3, Assessing Mindfulness and Acceptance Process in Clients, Ed. R.A. Bear). Canada: New Harbinger Publications.

Wood, A. M., Linley, P. A., Maltby, J., Baliousis, M., \& Joseph, S. (2008). The authentic personality: A theoretical and empirical conceptualization and the development of the Authenticity Scale. Journal of Counseling Psychology, 55(3), 385-399. https://doi.org/10.1037/0022-0167.55.3.385

\section{Copyrights}

Copyright for this article is retained by the author(s), with first publication rights granted to the journal.

This is an open-access article distributed under the terms and conditions of the Creative Commons Attribution license (http://creativecommons.org/licenses/by/4.0/). 